\title{
Phenolic constituents and biological activities of leaf extracts of traditional medicinal plant Plectranthus amboinicus Benth (Lamiaceae)
}

\author{
Sandeep Kumar Gupta ${ }^{1}$, Praveena Bhatt ${ }^{2}$, Gilbert Stanley Joseph ${ }^{3}$, Pradeep Singh Negi ${ }^{1, *}$, Mandyam Chakravarthy \\ Varadaraj $^{4}$ \\ ${ }^{1}$ Fruit and Vegetable Technology; ${ }^{2}$ Fermentation Technology and Bioengineering; ${ }^{3}$ Human Resource Development; ${ }^{4}$ Food \\ Microbiology CSIR-Central Food Technological Research Institute Mysore-570020, India
}

\begin{abstract}
Plectranthus amboinicus Benth (Lamiaceae) is a medicinal plant native to India, and its leaves are widely used in several traditional medicinal preparations. The purpose of this study was to detect and quantify phenolics present in ethyl acetate and acetone extracts of $P$. amboinicus leaves, and evaluate their antioxidant, antibacterial, antimutagenic and anticancer activities. The HPLC chromatograms of crude leaf extracts indicated the presence of phenolics like caffeic acid, coumaric acid, rutin, quercetin and gallic acid, which were present in the range of $0.01-1.41 \mathrm{mg} / \mathrm{g}$ in ethyl acetate and $0.03-1.93 \mathrm{mg} / \mathrm{g}$ in the acetone extract. The acetone extract showed statistically $(p<0.05)$ higher antioxidant activity $\left(\mathrm{IC}_{50}, 99.59 \mu \mathrm{g} / \mathrm{ml}\right)$ than ethyl acetate extract $\left(\mathrm{IC}_{50}, 149.96 \mu \mathrm{g} / \mathrm{ml}\right)$. Statistically $(p<0.05)$ higher antimutagenicity was shown by acetone extract (46.16\%) as compare to ethyl acetate extract $(12.16 \%)$ at $500 \mu \mathrm{g} /$ plate concentration. The acetone extract showed higher antibacterial activity than ethyl acetate extract, and both the extracts showed highest activity against $B$. cereus ( 375 and $625 \mu \mathrm{g} / \mathrm{ml}$, respectively) and lowest activity against $Y$. enterocolitica $(1000$ and $1125 \mu \mathrm{g} / \mathrm{ml}$, respectively). Both the extracts also showed inhibitory effect on cancer cell lines HCT-15 and MCF-7. These results suggest that the leaves of $P$. amboinicus possess various biological activities, and validate the traditional use of the leaves of $P$. amboinicus against cold, infection and ulceration.
\end{abstract}

Keywords antibacterial, anticancer, antimutagenic, antioxidant, phenolics, Plectranthus amboinicus

\section{INTRODUCTION}

Plectranthus amboinicus Benth (Lamiaceae) is a plant native to India (Khare et al., 2011), and its leaves are traditionally used in several medicinal preparations, especially for the treatment of coughs, sore throats, nasal congestion, and for a range of other problems such as infections, rheumatism and flatulence (Khory et al., 1999; Sharma and Singh, 2002). The plant is cultivated in home-gardens throughout India for use in traditional medicine to treat malarial fever, inflammation, hepatopathy, renal and gallstones, cough, chronic asthma, hiccough, bronchitis, helminthiasis, colic, convulsions, and epilepsy (Kaliappan and Viswanathan, 2008). Other traditional medicinal uses of leaves in India include against skin ulcerations, scorpion bite, skin allergy, wounds, diarrhoea, hepatoprotective, and to promote liver health (Shenoy et al., 2012). The plant is commonly used in home medication in several other countries, such as Indonesia, to stimulate lactation following childbirth; Cambodia to protect children from colds; and Brazil to treat skin lesions (Franca et al., 1996; Sousa et al., 2011).

There have been numerous research studies on hydroalcoholic extract of Indian borage leaves, and it was found to have anti-inflammatory (Patel et al., 2010),

\footnotetext{
*Correspondence: Pradeep Singh Negi

E-mail: psnegi@cftri.res.in

Received October 11, 2013; Accepted November 21, 2013; Published

November 30, 2013

doi: http://dx.doi.org/10.5667/tang.2013.0027

(C)2013 by Association of Humanitas Medicine
}

antitumorigenic and genotoxic, nephroprotective (Palani et al., 2010), anticancer (Gurgel et al., 2009) and antifungal properties (Murthy et al., 2009). In our earlier study on Indian borage leaves (Bhatt and Negi, 2012), we found that acetone and ethyl acetate extracts in sequential extraction showed higher activity than the hydroalcoholic extract. Therefore, in the present study, we have used the extracts prepared by using these solvents (acetone and ethyl acetate) individually to study their antioxidant, antimutagenic, cytotoxic and antibacterial potency. We have also identified and quantified a few potent bioactive molecules in these extracts.

\section{MATERIALS AND METHODS}

\section{Plant material}

The leaves of $P$. amboinicus were collected from the plants grown in the campus of Central Food Technological Research Institute (CFTRI), Mysore, India. The plant material was identified by Mr. A. S. Chauhan, Scientist, Fruit and Vegetable Technology Department, CFTRI, Mysore, and a specimen voucher was deposited in the Fruit and Vegetable Technology departmental herbarium (FVT DH No. LGMGHCC-PA-8/2011).

\section{Chemicals and reagents}

All the phenolics like caffeic acid, coumaric acid, rutin, quercetin and gallic acid; and 3-(4,5-dimethythiazol-2-yl)-2,5diphenyltetrazolium bromide (MTT), Dulbecco's Modified Eagle's Medium (DMEM), fetal bovine serum (FBS), and 
sodium pyruvate were purchased from Sigma Chemic Co. (Bengaluru, India). The 2, 2-diphenyl-1-picrylhydrazyl (DPPH) was obtained from Fluka (Bengaluru, India). All the microbiological media and sterilized plates were procured from HIMEDIA (Mumbai, India). Solvents and other chemicals used were of analytical grade.

\section{Extraction of polyphenols}

The fresh leaves of $P$. amboinicus were washed in running tap water and dried at low temperature $\left(55^{\circ} \mathrm{C}\right)$ in a hot air oven for $48 \mathrm{~h}$. The dried leaves (4 - 5\% moisture) were powdered using a mixer grinder and used for extraction with ethyl acetate and acetone $(1: 4 \mathrm{w} / \mathrm{v}$; leaf and solvent ratio) individually to obtain bioactive fractions. The extraction was done at room temperature by constant shaking for $24 \mathrm{~h}$, it was filtered with Whatman No 1 filter paper and the filtrate was concentrated in a fume hood to obtain the extract. The solvent free extracts were dissolved in methanol for antioxidant, antimutagenic and cytotoxic assays, and in propylene glycol (PG) for use in the antibacterial experiments.

\section{Determination of total phenols}

The concentration of phenols in the ethyl acetate and acetone leaf extracts was determined by the method of Singleton and Rossi (1965). Aliquots of the samples prepared in methanol were mixed with $1.0 \mathrm{ml}$ of 10 fold diluted Folin-Ciocalteu reagent and $1 \mathrm{ml}$ of saturated sodium carbonate solution. After allowing it to stand for $30 \mathrm{~min}$ at $30^{\circ} \mathrm{C}$, the absorbance was measured at $765 \mathrm{~nm}$ using a UV-visible spectrophotometer (Shimadzu, Japan). Total phenolics were calculated using a standard gallic acid curve and results were expressed as mg gallic acid equivalents (GAE)/g extract.

\section{High performance liquid chromatography (HPLC)}

HPLC was performed in Shimadzu unit (LC 10A, SPDMOAVP, Kyoto, Japan) equipped with a quaternary pump and a diode array detector. The mobile phase involved a gradient of water: acetic acid (100:1) as solvent A and methanol: acetonitrile: acetic acid (95:5:1) as solvent B at a constant flow rate of $1.0 \mathrm{ml} / \mathrm{min}$. The gradient comprised of an initial isocratic period of $2 \mathrm{~min}$ with $5 \%$ solvent $\mathrm{B}$, followed by a linear increase to $25 \%$ with $\mathrm{B}$ over $10 \mathrm{~min}$ with further stepwise linear increase to $40 \% \mathrm{~B}$ in $20 \mathrm{~min}, 50 \% \mathrm{~B}$ in $30 \mathrm{~min}$ and $100 \% \mathrm{~B}$ in $40 \mathrm{~min}$, which was maintained for $5 \mathrm{~min}$ and returned to initial conditions in next $10 \mathrm{~min}$. Samples were dissolved in methanol, and $20 \mu \mathrm{l}$ sample was injected for chromatographic separation. The compounds were identified by comparing their retention times with those of standards at 325 $\mathrm{nm}$ with the exception of gallic acid (observed at $280 \mathrm{~nm}$ ). The quantity of the various compounds present was determined from the standard curve using the standards for individual phenolic compounds obtained from Sigma Aldrich, Bengaluru, India.

\section{Free radical scavenging assay}

The free radical scavenging activity of the acetone and ethyl acetate leaf extracts was measured in vitro by DPPH assay (Blois, 1958). Aliquots of the samples $(1000 \mu \mathrm{g} / \mathrm{ml})$ adjusted to a final volume of $2.5 \mathrm{ml}$ were mixed with $5 \mathrm{ml}$ of $0.1 \mathrm{mM}$ DPPH solution. The tubes were shaken properly and incubated for $20 \mathrm{~min}$ in the dark. The change in the absorbance of the samples was measured at $517 \mathrm{~nm}$ using a spectrophotometer. The radical scavenging activity of the extracts at different concentrations was determined and compared with that of butylated hydroxyanisole (BHA), which was used as the standard. DPPH solution without extract/standard formed the control. The percentage DPPH radical scavenging activity was calculated as following-

$\%$ DPPH radical scavenging activity

$$
=100 \times\left(\mathrm{A}_{0}-\mathrm{A}_{\mathrm{s}}\right) / \mathrm{A}_{0} \text {..... }
$$

where $A_{0}$ is absorbance of control and $A_{s}$ is the absorbance of the sample. Antioxidant activity was also expressed as half maximal inhibitory concentration $\left(\mathrm{IC}_{50}\right)$, defined as the concentration of extracts $(\mu \mathrm{g} / \mathrm{ml})$ causing a $50 \%$ decrease in initial DPPH radical absorbance at $517 \mathrm{~nm}$. IC $_{50}$ values in DPPH assay were calculated from the graph plotting inhibition percentage against extract concentration.

\section{Total antioxidant capacity}

The total antioxidant capacity of acetone and ethyl acetate extract of the leaves of Indian borage was evaluated using the phosphomolybdenum method (Prieto et al., 1999). An aliquot of $0.3 \mathrm{ml}$ of extract samples $(1000 \mu \mathrm{g} / \mathrm{ml})$ was combined with a mixture of $3 \mathrm{ml}$ of reagent solution ( $0.6 \mathrm{M}$ sulphuric acid, 28 $\mathrm{mM}$ sodium phosphate and $4 \mathrm{mM}$ ammonium molybdate). The tubes containing the reaction solution were capped and incubated at $95^{\circ} \mathrm{C}$ for $90 \mathrm{~min}$. After the samples had cooled to ambient temperature, the absorbance of the solution was measured at $695 \mathrm{~nm}$ against reagent blank containing the respective solvents. Ascorbic acid was used as a positive control and results were expressed as $\mu \mathrm{M}$ Ascorbic acid equivalents $(\mathrm{AAE}) / \mathrm{g}$ extract.

\section{Antimutagenicity assay}

Salmonella typhimurium mutant strains TA-98 and TA-1538 were procured from Microbial Type Culture Collection (MTCC), Institute of Microbial Technology (IMT), Chandigarh, India, and grown according to the supplier's instruction. The antimutagenicity of acetone and ethyl acetate extracts of leaves at different concentration (500, 1000 and $2000 \mu \mathrm{g} /$ plate) was assayed by plating the extracts with molten soft agar containing $10 \mathrm{~h}$ old $S$. typhimurium culture onto minimal glucose agar plates (Maron and Ames, 1983). Sodium azide was used as a diagnostic mutagen $(1.5 \mu \mathrm{g}$ per plate) in positive control and plates without sodium azide and without test samples were considered as negative controls. His ${ }^{+}$revertants were counted after incubation of the plates at $37^{\circ} \mathrm{C}$ for $48 \mathrm{~h}$. Each sample was assayed using duplicate plates and the data presented here are mean \pm SD of three independent assays. The inhibition of mutagenicity was calculated as-

$\%$ inhibition

$$
=[1-\mathrm{T} / \mathrm{M}] \times 100 \text {. }
$$

where $\mathrm{T}$ is the number of revertants per plate in the presence of mutagen and test sample, and $\mathrm{M}$ is the number of revertants per plate in positive control. The number of spontaneous revertants (negative control) was subtracted from the numerator and denominator. Based on \% inhibition, the antimutagenic effect was defined as weak $(<25 \%)$, moderate $(25-40 \%)$, and strong (> 40\%) (Ikken et al., 1999).

\section{Anticancer activity}

The human cancer cells, Caco-2 (human adenocarcinoma), HCT-15 (human colon adenocarcinoma) and MCF-7 (human mammary gland; breast adenocarcinoma) were purchased from National Centre for Cell Science (NCCS), Pune, India. The cells were cultured in DMEM with 10 or $20 \%$ FBS, sodium pyruvate and penstrep and maintained at $37^{\circ} \mathrm{C}$ with $5 \% \mathrm{CO}_{2}$ in a humidified atmosphere (Galaxy 170S, Newbrunswick, USA). The cytotoxic activity of the extracts on various cell lines was measured by MTT assay essentially as described in Bhatt et al. (2013). Cells in exponential growth phase were placed in 96well plate to make - 6000 cells/well, and extract was added at 
concentrations ranging from $3.125-100 \mu \mathrm{g}$ in $100 \mu \mathrm{l}$ final volumes in different wells, and it was incubated at $37^{\circ} \mathrm{C}$ with $5 \% \mathrm{CO}_{2}$ for $68 \mathrm{~h}$. DMEM was used in place of the extracts as a negative control. Cell proliferation was determined by adding $20 \mu 1$ of MTT $(0.5 \mathrm{mg} / \mathrm{ml})$, and it was incubated further at $37^{\circ} \mathrm{C}$ with $5 \% \mathrm{CO}_{2}$ for $4 \mathrm{~h}$. After incubation, the formazone crystals were dissolved in equal volume of MTT solubilizing solution $(0.1 \mathrm{~N} \mathrm{HCl}$ in anhydrous isopropanol with $10 \%$ TRITON X-100). The quantity of blue formazone was measured at $595 \mathrm{~nm}$ using a microplate reader (iMARK, Bio$\mathrm{RAD}$, Japan). Data were obtained from three independent assays, using 3 wells for each assay. Cytotoxicity was determined based on the percent cell viability.

\section{Antibacterial activity}

The bacterial cultures, Bacillus cereus F 4810 (Public Health Laboratory, London, UK), Staphylococcus aureus FRI 722 (Public Health Laboratory, The Netherlands), Escherichia coli MTCC 108 (MTCC, IMT, Chandigarh, India) and Yersinia enterocolitica MTCC 859 (MTCC, IMT, Chandigarh, India) were grown in Brain Heart Infusion (BHI) Agar at $37^{\circ} \mathrm{C}$. Each bacterial strain was transferred from stored slants at $4-5^{\circ} \mathrm{C}$ to $10 \mathrm{ml} \mathrm{BHI} \mathrm{broth} \mathrm{and} \mathrm{cultivated} \mathrm{overnight} \mathrm{at} 37^{\circ} \mathrm{C}$ for $24 \mathrm{~h}$. A pre-culture was prepared by transferring $1 \mathrm{~mL}$ of this culture to $9 \mathrm{ml} \mathrm{BHI}$ broth and cultivated for $24 \mathrm{~h}$ at $37^{\circ} \mathrm{C}$. The cells were harvested by centrifugation at $5000 \mathrm{rpm}$ for $10 \mathrm{~min}$, washed and suspended in saline solution $(0.85 \% \mathrm{NaCl}, \mathrm{w} / \mathrm{v})$.

The leaf extracts of $P$. amboinicus were tested against selected food borne pathogens by the agar dilution method (Negi et al., 1999). One hundred $\mu$ of bacterial culture diluted to $10^{3} \mathrm{cfu} / \mathrm{ml}$ was inoculated into the flask containing $20 \mathrm{ml}$ nutrient agar and different concentrations of leaf extracts, and the contents were poured into sterilized petri plates. The plates were observed for bacterial growth after overnight incubation at $37^{\circ} \mathrm{C}$, and the minimum inhibitory concentration (MIC) was determined as the lowest concentration of the extract capable of inhibiting the complete growth of bacteria.

\section{Statistical analysis}

All the experiments were performed in triplicate, and the values were reported as mean \pm SD $(n=3)$. The effect of acetone and ethyl acetate extract on various bioactivities was compared using $t$-test performed in Microsoft Excel.

\section{RESULTS AND DISCUSSION}

\section{Phenolics in leave extracts}

The total phenolics in terms of GAE were significantly higher $(p<0.01)$ in the acetone extract $(85.15 \pm 1.18 \mathrm{GAE} / \mathrm{g}$ extract $)$ than ethyl acetate $(67.83 \pm 1.10 \mathrm{GAE} / \mathrm{g}$ extract). In HPLC, the presence of some known bioactive molecules was observed (Fig. 1). The acetone extract contained caffeic acid $(0.068 \mathrm{mg})$, coumaric acid $(0.137 \mathrm{mg})$, rutin $(0.283 \mathrm{mg})$, quercetin $(1.933$ $\mathrm{mg})$ and gallic acid $(0.033 \mathrm{mg})$ per gram of dried extract, while ethyl acetate extract had caffeic acid $(0.054 \mathrm{mg})$, coumaric acid $(0.097 \mathrm{mg})$, rutin $(0.207 \mathrm{mg})$, quercetin $(1.418 \mathrm{mg})$ and gallic acid $(0.012 \mathrm{mg})$ per gram of dried extract. Although, the amount of the identified phenolics was less in the ethyl acetate crude extract in comparison to acetone, the order of phenolics in terms of quantity was similar for both the extracts (quercetin $>$ rutin > coumaric > caffeic acid > gallic acid). Both the extracts showed appreciable antioxidant, antibacterial and anticancer properties, and the difference in quantities of individual phenolics may be responsible for the differences in the biological activities of these extracts. It is possible that these biomolecules may be responsible for the observed biological activities in the acetone and ethyl acetate extracts of the leaves. Bioactive molecules in the leaves $P$. amboinicus, especially phenolics and flavonoids like carvacrol, thymol, $\beta$ caryophyllene, quercetin, chlorogenic acid, rosmarinic acid and eugenol have been thought to be responsible for their pharmacological properties (Khare et al., 2011).

(A)

(B)
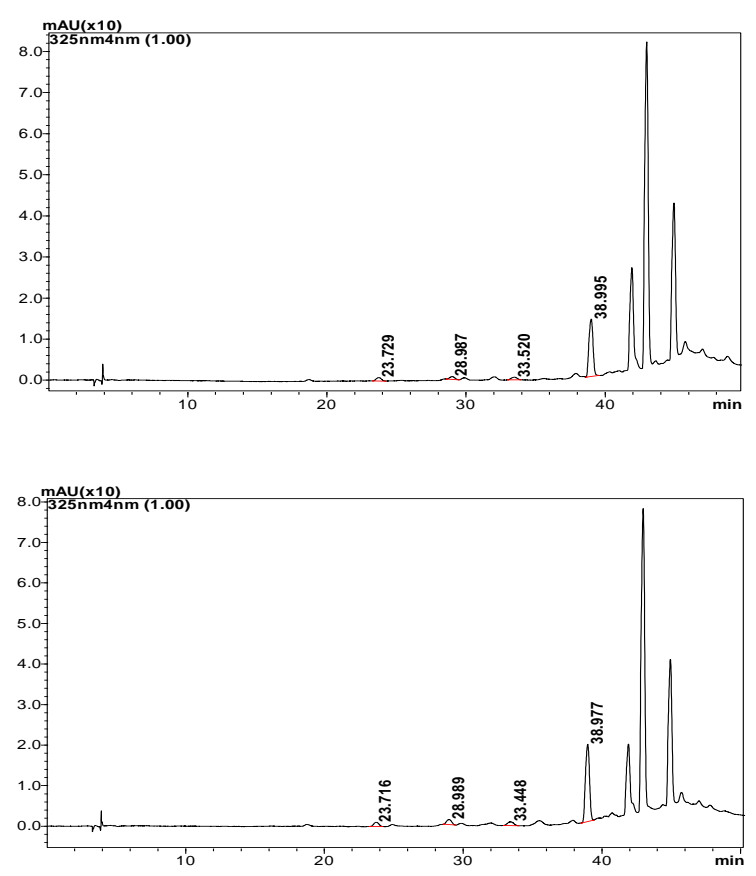

Fig. 1. HPLC chromatograms of (A) acetone extracts and (B) ethyl acetate of extracts of the leaves of $P$. amboinicus- Retention time in min at $325 \mathrm{~nm}$ [caffeic acid $(23.7 \mathrm{~min})$, coumaric acid $(28.9 \mathrm{~min})$, rutin (33.4 $\mathrm{min})$, and quercetin (38.9 $\mathrm{min})]$

\section{Antioxidant activity of leaves extracts}

Although, the total antioxidant capacity determined using the phosphomolybdenum method showed higher total antioxidant capacity for the acetone extract $(1813.48 \pm 0.046 \mu \mathrm{M} \mathrm{AAE} / \mathrm{g}$ extract) as compared to ethyl acetate extract (1778.34 \pm 0.027 $\mu \mathrm{M}$ AAE/g extract), the difference was not statistically significant $(p<0.05)$. However, acetone extract of the leaves showed an appreciable DPPH radical scavenging activity at $200 \mu \mathrm{g} / \mathrm{ml}(\sim 79 \%)$, which was significantly higher $(p<0.001)$ than ethyl acetate $(58 \%)$ at the same concentration (Table 1).

DPPH radical scavenging activity in terms of $\mathrm{IC}_{50}$ values for acetone extract $(99.8 \mu \mathrm{g} / \mathrm{ml})$ was significantly lower $(p<$ $0.01)$ than ethyl acetate extract $(149.9 \mu \mathrm{g} / \mathrm{ml})$ indicating better free radical scavenging capacity of acetone extract. Salar and Seasotiya (2011) also reported exceptionally high scavenging activity in acetone extract as compared to ethyl acetate extracts of $B$. monosperma. Higher DPPH radical scavenging activity and total antioxidant capacity observed in the acetone extract of leaves relative to ethyl acetate extract in the present study may probably be due to differences in their phenolics (Aydemir and Becerik, 2011; Guleria et al., 2013; Negi et al., 2008; 2010), as phenolics are reported to contribute to the antioxidant activity of leaf extracts (Fu et al., 2013; Guo et al., 2013; Huang et al., 2013). However, the DPPH radical scavenging activity of both the extracts was lower compared to the synthetic antioxidant, BHA $(\sim 95 \%$ at $60 \mu \mathrm{g} / \mathrm{ml})$, which was used as the standard antioxidant. 
Table 1. DPPH radical scavenging activity of ethyl acetate and acetone extracts of leaves of P. amboinicus

\begin{tabular}{lccc}
\hline $\begin{array}{c}\text { Concentration } \\
(\mu \mathrm{g} / \mathrm{ml})\end{array}$ & \multicolumn{2}{c}{ \% DPPH radical scavenging activity } \\
\cline { 2 - 4 } 20 & BHA & $\begin{array}{c}\text { Ethyl acetate } \\
\text { extract }\end{array}$ & Acetone extract \\
40 & $89.89 \pm 0.20$ & $23.93 \pm 0.28$ & $21.85 \pm 0.29^{*}$ \\
60 & $92.38 \pm 0.10$ & $29.46 \pm 0.13$ & $27.81 \pm 0.45^{* *}$ \\
80 & $94.07 \pm 0.03$ & $32.58 \pm 0.08$ & $33.50 \pm 0.31^{* *}$ \\
100 & $94.41 \pm 0.02$ & $34.57 \pm 0.94$ & $41.89 \pm 6.18^{\text {NS }}$ \\
120 & $93.83 \pm 0.10$ & $38.83 \pm 0.07$ & $55.50 \pm 0.28^{* * *}$ \\
140 & $96.83 \pm 0.02$ & $44.77 \pm 2.24$ & $61.48 \pm 0.23^{* *}$ \\
160 & $96.83 \pm 0.01$ & $50.22 \pm 3.06$ & $66.36 \pm 0.13^{* *}$ \\
180 & $96.83 \pm 0.01$ & $52.68 \pm 0.53$ & $71.24 \pm 2.06^{* *}$ \\
200 & $96.83 \pm 0.01$ & $56.37 \pm 0.60$ & $76.12 \pm 0.00^{* *}$ \\
\hline All & $96.83 \pm 0.02$ & $58.05 \pm 0.24$ & $79.86 \pm 0.33^{* * *}$ \\
\hline
\end{tabular}

All values are mean \pm SD $(n=3)$; Statistical analysis by $t$-test; Difference between ethyl acetate and acetone extract at a particular concentration. ${ }^{*} p<0.05 ;{ }^{* *} p<0.01 ;{ }^{* * *} p<0.001$; NS, Non-significant.

\section{Antimutagenic activity of leaf extracts}

The antimutagenic effect of acetone and ethyl acetate extracts against sodium azide induced mutation in S. typhimurium strains TA-98 and TA-1538 was evaluated by Ames test at various concentrations ranging from $500-2000 \mu \mathrm{g} / \mathrm{plate}$ (Fig. 2 ). Both the extracts showed strong antimutagenic activity at $2000 \mu \mathrm{g} / \mathrm{plate}$ concentration for both the strains. In case of TA1538 , both the extracts showed moderate antimutagenic activity at $500 \mu \mathrm{g} / \mathrm{plate}$ and strong activity at $1000 \mu \mathrm{g} /$ plate concentration. However, in case of TA-98, acetone extract showed strong antimutagenic activity $(46.16 \%)$ at $500 \mu \mathrm{g} / \mathrm{plate}$, whereas ethyl acetate extract had weak activity $(12.56 \%)$ at similar concentration. Although, acetone extract showed higher antimutagenicity in both the strains than ethyl acetate extract, the difference in antimutagenicity was significant $(p<0.01)$ only for TA-98 strain at $500 \mu \mathrm{g} /$ plate concentration.
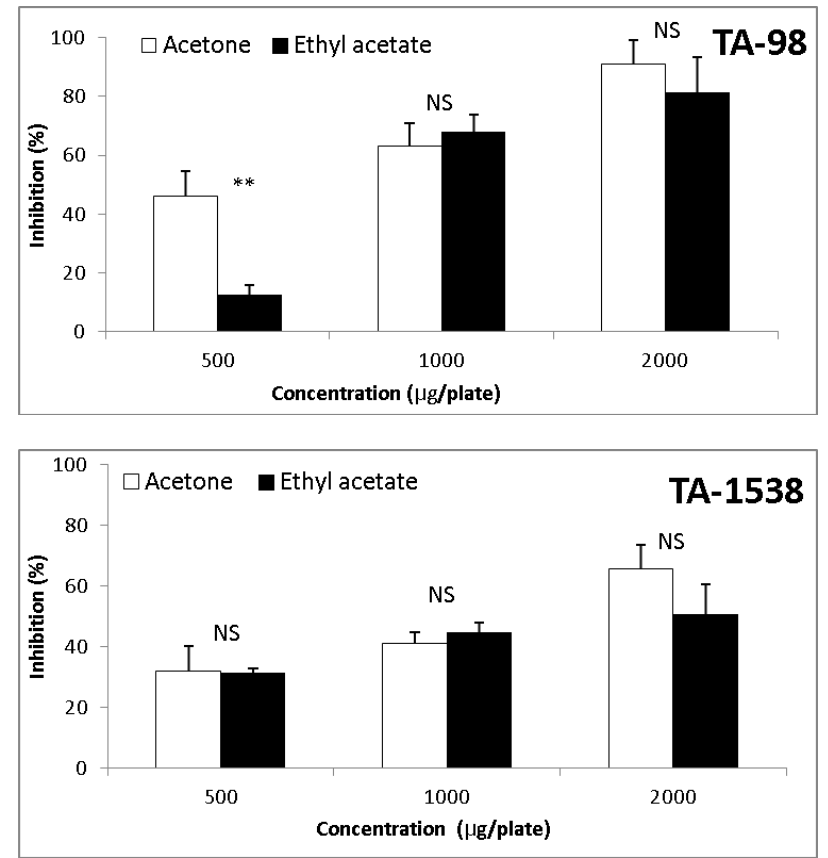

Fig. 2. Antimutagenic activity of ethyl acetate and acetone extract of $P$. amboinicus leaves against $S$. typhimurium TA-98 and TA 15 38. All values are mean \pm SD $(\mathrm{n}=3)$; Statistical analysis by $t$-test; Difference between ethyl acetate and acetone extract at a particular concentration. ${ }^{* *} p<0.01$; NS, Non-significant.

Mutation induced by mutagens can be reduced by active oxygen scavengers, and compounds that possess antioxidant activity are reported to inhibit mutation and cancer (Hochstein and Atallah, 1988). We also observed both the antioxidant and antimutagenic effects in leaf extracts, similar to Garcinia fruit extracts reported earlier (Jayaprakasha et al., 2006; Negi et al., 2008). It has been observed that many plant polyphenols such as catechins, ellagic, chlorogenic, caffeic and ferulic acids act as potent antimutagenic agents (Edenharder and Tang, 1997), and the presence of these compounds in leaf extract may be responsible for their antimutagenic activity in the present study. The variable antimutagenic activity may be attributed to the differences in quality and quantity of phenolics in these extracts as was reported earlier for cinnamon fruit extracts (Jayaprakasha et al., 2007).

\section{Anticancer activity of leaf extracts}

The acetone and ethyl acetate extracts were evaluated for their cytotoxic effect on three cancer cell lines namely Caco-2, HCT15 and MCF-7. The extracts showed variable effects on the cell lines but were found to have cytotoxic effect on all three of them (Table 2). The ethyl acetate extract showed a significantly higher $(p<0.05)$ inhibitory effect than acetone extract on cancer cell lines HCT-15 and MCF-7 at 500 and $1000 \mu \mathrm{g} / \mathrm{ml}$ concentrations, however, the cytotoxic effect of the ethyl acetate extract was statistically similar $(p<0.05)$ to acetone extract on Caco-2 at both the concentrations. Plant extracts are known to show cytotoxic effect (Sikdar et al., 2013), and the cytotoxic effect of Indian borage extracts was probably due to the presence of phenolics as reported in Terminalia chebula decoction (Pellati et al., 2013). A dose dependent increase in the cell cytotoxicity was seen with both the extracts in the tested concentration range of $31.25-1000 \mu \mathrm{g} / \mathrm{ml}$, similar to carrot oil extracts observed in the range of $10-100 \mu \mathrm{g} / \mathrm{ml}$ (Shebaby et al., 2013).

\section{Antibacterial activity of leaf extracts}

The ethyl acetate and the acetone extracts were evaluated for their antibacterial activity against selected food borne pathogens. The acetone extract was found to have the highest antibacterial activity against B. cereus (MIC, $375 \mu \mathrm{g} / \mathrm{ml}$ ) and lowest against $Y$. enterocolitica (MIC, $1000 \mu \mathrm{g} / \mathrm{ml}$ ). A similar trend was observed for the ethyl acetate extract which also showed the highest antibacterial activity against $B$. cereus and E. coli (MIC, $625 \mu \mathrm{g} / \mathrm{ml}$ for both) and least activity against $Y$. enterocolitica (MIC, $1125 \mu \mathrm{g} / \mathrm{ml}$ ). Although, it is generally reported that plant extracts have higher activity against Gram positive bacteria than Gram negative bacteria because of the difference in their cell wall, the extracts were equally active against both Gram positive as well as Gram negative organisms with antibacterial activity in the order of B. cereus $<$ E.coli $<S$. aureus < $Y$. enterocolitica. However, Chukwujekwu et al. (2011) reported higher sensitivity of Gram negative bacteria against flavonoids isolated from stem bark of Erythrina caffra and the trend was $K$. pneumonia $<$ E. coli $<$ B. subtilis $<S$. aureus. Different extracts have variable antibacterial activity depending on the type of bioactives present in them, which may vary with the extraction procedure, assay method and bacterium in question (Negi, 2012).

In conclusion, the acetone and ethyl acetate extracts of Indian borage leaves were found to be rich in bioactive compounds. They exhibited appreciable antioxidant, antimutagenic and antibacterial activities. These extracts also showed an anti-proliferative effect on human cancer cell lines. These biological activities can be attributed to the phenolics present in the acetone and ethyl acetate extracts. These results contribute towards validation of traditional use of the leaves of $P$. amboinicus against cold, infection and ulceration. 
Table 2. Anticancer activity of ethyl acetate and acetone extract of the leaves of $P$. amboinicus

\begin{tabular}{|c|c|c|c|c|c|c|}
\hline \multicolumn{7}{|c|}{ \% Inhibition of cell proliferation } \\
\hline \multirow{2}{*}{$\begin{array}{l}\text { Concentration } \\
(\mu \mathrm{g} / \mathrm{ml})\end{array}$} & \multicolumn{2}{|c|}{ Caco-2 } & \multicolumn{2}{|c|}{ HCT-15 } & \multicolumn{2}{|c|}{ MCF-7 } \\
\hline & $\begin{array}{c}\text { Ethyl acetate } \\
\text { extract }\end{array}$ & Acetone extract & $\begin{array}{c}\text { Ethyl acetate } \\
\text { extract }\end{array}$ & Acetone extract & $\begin{array}{c}\text { Ethyl acetate } \\
\text { extract }\end{array}$ & Acetone extract \\
\hline 31.25 & $18.7 \pm 1.8$ & $14.3 \pm 7.6^{\mathrm{NS}}$ & $9.3 \pm 1.9$ & $9.6 \pm 7.2^{\mathrm{NS}}$ & $1.3 \pm 0.3$ & $7.8 \pm 0.5^{* *}$ \\
\hline 62.5 & $26.6 \pm 8.4$ & $29.3 \pm 3.9^{\mathrm{NS}}$ & ND & ND & $6.6 \pm 1.7$ & $8.4 \pm 0.9^{\mathrm{NS}}$ \\
\hline 125 & $31.6 \pm 6.8$ & $37.4 \pm 5.1^{*}$ & $17.9 \pm 2.0$ & $11.4 \pm 2.7^{\mathrm{NS}}$ & $21.8 \pm 1.4$ & $10.0 \pm 1.7^{* *}$ \\
\hline 250 & $60.0 \pm 5.3$ & $48.3 \pm 6.3^{\mathrm{NS}}$ & $15.2 \pm 2.9$ & $14.8 \pm 11.6^{\mathrm{NS}}$ & $22.8 \pm 3.8$ & $17.7 \pm 2.7^{\mathrm{NS}}$ \\
\hline 500 & $64.4 \pm 4.3$ & $57.9 \pm 7.2^{\mathrm{NS}}$ & $34.1 \pm 5.2$ & $21.6 \pm 3.9^{* *}$ & $32.0 \pm 0.8$ & $21.8 \pm 4.8^{*}$ \\
\hline 1000 & $62.5 \pm 1.5$ & $64.1 \pm 3.0^{\mathrm{NS}}$ & $76.0 \pm 5.1$ & $59.1 \pm 1.3^{*}$ & $38.35 \pm 3.0$ & $25.9 \pm 3.4^{*}$ \\
\hline
\end{tabular}

All values are mean \pm SD $(\mathrm{n}=3)$; Statistical analysis by $t$-test; Difference between ethyl acetate and acetone extract at a particular concentration for each cell line. ${ }^{*} p<0.05 ;{ }^{* *} p<0.01$; NS, Non-significant; ND, not determined

\section{ACKNOWLEDGEMENTS}

The authors wish to express sincere thanks to Director, CSIRCFTRI for his keen interest and constant encouragement. Authors also thank Mr. A. S. Chauhan, Principal Scientist, Fruit and Vegetable Technology Department, CSIR-CFTRI, Mysore for identification of plant material.

\section{CONFLICT OF INTEREST}

None to declare.

\section{REFERENCES}

Aydemir T, Becerik S. Phenolic content and antioxidnt activity of different extracts from Ocimum basilicum, Apium graveolens and Lepidium sativum seeds. J Food Biochem. 2011;35:62-79.

Bhatt P, Joseph GS, Negi PS, Varadaraj MC. Chemical composition and nutraceutical potential of Indian borage (Plectranthus amboinicus) stem extract. J Chem. 2013:Article ID 320329.

Bhatt P, Negi PS. Antioxidant and antibacterial activities in the leaf extracts of Indian borage (Plectranthus amboinicus). Food Nutr Sci. 2012;3:146-152.

Blois MS. Antioxidant determinations by the use of a stable free radical. Nature. 1958;181:1199-1200.

Chukwujekwu JC, Van Heerden FR, Van Staden J. Antibacterial activity of flavonoids from the stem bark of Erythrina caffra Thunb. Phytother Res. 2011;25:46-48.

Edenharder R, Tang X. Inhibition of the mutagenicity of 2nitrofluorene, 3-nitrofluoranthene and 1-nitropyrene by flavonoids, coumarines, quinines and other phenolic compounds. Food Chem Toxicol. 1997;35:357-372.

Franca F, Lago EL, Marsden PD. Plants used in the treatment of leishmanial ulcers due to Leishmania (Vannia) braziliensis in an endemic area of Bahia, Brazil. Rev Soc Bras Med Trop. 1996;29:229-232.

Fu R, Zhang YT, Guo YR, Huang QL, Peng T, Xu Y, Tang L, Chen F. Antioxidant and anti-inflammatory activities of the phenolic extracts of Sapium sebiferum (L.) Roxb. leaves. J Ethnopharmacol. 2013;147:517-524.

Guleria S, Tiku AK, Singh G, Koul A, Gupta S, Rana S. In vitro antioxidant activity and phenolic contents in methanol extracts from medicinal plants. J Plant Biochem Biotech. 2013;22:9-15.

Guo XF, Yue YD, Tang F, Wang J, Yao X. Antioxidant properties of major flavonoids and subfractions of the extract of Phyllostachys pubescens leaves. J Food Biochem. 2013;37:501-509.

Gurgel AP, da Silva JG, Grangeiro AR, Oliviera DC, Lima CM, da Silva AC, Oliviera RA, Souza IA. In vivo study of the antiinflammatory and antitumor activities of leaves from Plectranthus amboinicus (Lour.) Spreng (Lamiaceae). J Ethnopharmacol. 2009;125:361-363.

Hochstein P, Atallah AS. The nature of oxidant and antioxidant systems in the inhibition of mutation and cancer. Mutat Res. 1988;202:363-375.

Huang SS, Chiu CS, Lin TH, Lee MM, Lee CY, Chang SJ, Hou WC, Huang GJ, Deng JS. Antioxidant and anti-inflammatory activities of aqueous extract of Centipeda minima. J Ethnopharmacol. 2013;147:395-405.

Ikken Y, Morales P, Martínez A, Marín ML, Haza AI, Cambero MI. Antimutagenic effect of fruit and vegetable ethanolic extracts against N-nitrosamines evaluated by the Ames test. J Agric Food Chem. 1999;47:3257-3264.

Jayaprakasha GK, Negi PS, Jena BS, Rao LJM. Antioxidant and antimutagenic activities of Cinnamomum zeylanicum fruit extracts. J Food Comp Anal. 2007;20:330-336.

Jayaprakasha GK, Negi PS, Jena BS. Antioxidative and antimutagenic activities of the extracts from the rinds of Garcinia pedunculata. Innov Food Sci Emer Technol. 2006; 7:246-250.

Kaliappan ND, Viswanathan PK. Pharmacognostical studies on the leaves of Plectranthus amboinicus (Lour) Spreng. Int J Green Pharma. 2008;2:182-184.

Khare RS, Banerjee S, Kundu K. Coleus aromaticus Benth- A nutritive medicinal plant of potential therapeutic value. Int $\mathrm{J}$ Pharma Bio sci. 2011;2:B488 - B500.

Khory NR, Katrak NN. Materia Medica of India and their Therapeutics. (New Delhi, India: Neeraj Pub.), 1903.

Maron DM, Ames BN. Revised methods for the Salmonella mutagenicity test. Mutat Res. 1983;113:173-215.

Murthy PS, Ramalakshmi K, Srinivas P. Fungitoxic activity of Indian borage (Plectranthus amboinicus) volatiles. Food Chem. 2009;114:1014-1018. 
Negi PS, Jayaprakasha GK, Jena BS. Evaluation of antioxidant and antimutagenic activities of the extracts from the fruit rinds of Garcinia cowa. Int J Food Prop. 2010;13:1256-1265.

Negi PS, Jayaprakasha GK, Rao LJM, Sakariah KK. Antibacterial activity of turmeric oil: A byproduct from curcumin manufacture. J Agric Food Chem. 1999;47:42974300 .

Negi PS, Jayaprakasha GK., Jena BS. 2008. Antibacterial activity of the extracts from the fruit rinds of Garcinia cowa and Garcinia pedunculata against food borne pathogens and spoilage bacteria. LWT-Food Sci Technol. 2008;41:1857-1861.

Negi PS. Plant extracts for the control of bacterial growth: Efficacy, stability and safety issues for food application. Int $\mathbf{J}$ Food Microbiol. 2012;156:7-17.

Palani S, Raja S, Naresh R, Kumar BS. Evaluation of nephroprotective, diuretic and antioxidant activities of Plectranthus amboinicus on acetaminophen-induced nephrotoxic rats. Toxicol Mech Methods. 2010;20:213-221.

Patel R, Mahobia NK, Ghendle R, Kaushik B, Singh SK. Diuretic activity of leaves of Plectranthus amboinicus (Lour) Spreng in male albino rats. Pharmocognosy Res. 2010;2:86-88.

Pellati F, Bruni R, Righi D, Grandini A, Tognolini M, Prencipe FP, Poli F, Benvenuti S, Rio DD, Rossi D. Metabolite profiling of polyphenols in a Terminalia chebula Retzius ayurvedic decoction and evaluation of its chemopreventive activity. J Ethnopharmacol. 2013;147:277-285.

Prieto P, Pineda M, Aguilar M. Spectrophotometric quantitation of antioxidant capacity through the formation of phosphomolybdenum complex: Specific application for the determination of Vitamin E. Anal Biochem. 1999;269:337-341.

Salar RK, Seasotiya L. Free radical scavenging activity, phenolic contents and phytochemical evaluation of different extracts of stem bark of Butea monosperma (Lam.) Kuntze. Front Life Sci. 2011;5:107-116.

Sharma P, Singh G. A review of plant species used to treat conjunctivitis. Phytother Res. 2002;16:1-22.

Shebaby WN, El-Sibai M, Smith KB, Karam MC, Mroueh M, Daher CF. The antioxidant and anticancer effects of wild carrot oil extract. Phytother Res. 2013;27:737-744.

Shenoy S, Kumar H, Thashma, Nayak V, Prabhu K, Pai P, Warrier I, Somaya, Madhav V, Bairy KL, Kishore A. Hepatoprotective activity of Plectranthus amboinicus against paracetamol hepatotoxicity in rats. Int J Pharmacol Clin Sci. 2012;1:32-38.

Sikdar S, Mukherjee A, Boujedaini N, Khuda-Bukhsh AR. Ethanolic extract of Condurango (Marsdenia condurango) used in traditional systems of medicine including homeopathy against cancer can induce DNA damage and apoptosis in non small lung cancer cells, A549 and H522, in vitro. TANG. 2013;3:e9.

Singleton VL, Rossi JA. Colorimetry of total phenolics with phosphomolybdic-phosphotungstic acid reagents. Am J Enol Vitic. 1965;16:144-158.

Sousa LCFS, Sousa JEDS, Sousa JDS, Wanderley JAC, Borges MDGB. Ethnobotany knowledge of public school students in the city of Pombal-PB. Revista Verde De Agroecologia E Desenvolvimento ustentavel. 2011;6:139-145. 